\title{
Epipodophyllotoxin VP 16213 in Treatment of Acute Leukaemias, Haematosarcomas, and Solid Tumours
}

\author{
European Organization for Research on the Treatment of Cancer, Clinical Screening Group*
}

British Medical fournal, 1973, 3, 199-202

\section{Summary}

Epipodophyllotoxin VP 16213 (4-demethyl-epipodophyllotoxin- $\beta$-D-ethylidene glucoside), given to 250 patients with various types of malignant disease, induced apparently complete remissions in four out of eight cases of acute monocytoid and acute myelomonocytoid leukaemia but only one complete regression and six incomplete remissions in 21 cases of reticulosarcoma. Incomplete regressions occurred in patients with Hodgkin's disease, lymphosarcoma, melanoma, and carcinoma of the breast, ovary, testis, bladder, kidney, and thyroid. Seemingly complete regressions of malignant pleural effusion occurred when the drug was given systemically. Toxic side effects interfered with treatment in $\mathbf{4 0}$ patients but stopped it in only nine. No signs of toxicity were seen in 114 patients and in 85 the side effects were negligible. VP 16213 represents an advance in the treatment of acute monocytoid leukaemia, which has been up till now insensitive to any drug.

\section{Introduction}

Epipodophyllotoxin VP 16213 (4-demethyl-epipodophyllotoxin$\beta$-D-ethylidene glucoside) (see formula) is a semisynthetic derivative of podophyllotoxin. It is chemically related to epipodophyllotoxin VM 26 (4-demethyl-epipodophyllotoxin- $\beta$-Dthenyl glucoside), a derivative which is effective in reticulosarcoma, Hodgkin's disease, and bladder carcinoma (E.O.R.T.C., 1972). VP 16213 has a cytostatic action in vitro which prevents the cells from entering mitosis or destroys them in the premitotic phase (Stähelin, 1970), and it has an oncostatic action in vivo on L 1210 leukaemia, P 815 mastocytoma, and P 1534 leukaemia (Stähelin, 1970).

We have carried out a clinical phase II screening trial to detect the possible sensitivity of human tumours to VP 16213. Because of its kinship to VM 26 patients with reticulosarcoma, Hodgkin's

- Members participating in the trial: G. Brule; F. Cabanne; F. Cappelaere A. Cattan; C. Cauchie ; F. Cheix; B. Clavel; P. F. Combes; J. Gary-Bobo O. Godin; J. Guérin; S. Hane; M. Hayat (Secretary); C. Jeanne; R. Keiling T. Klein; T. J. Kuipers; G. Mathe (Councillor); F. May Levin; J. F. Pollet; E. Pommatau; P. Pouillart; S. Schraub; L. Schwarzenberg; P. Serpantie; J. Tardiveau (Chairman); F. de Vassal.

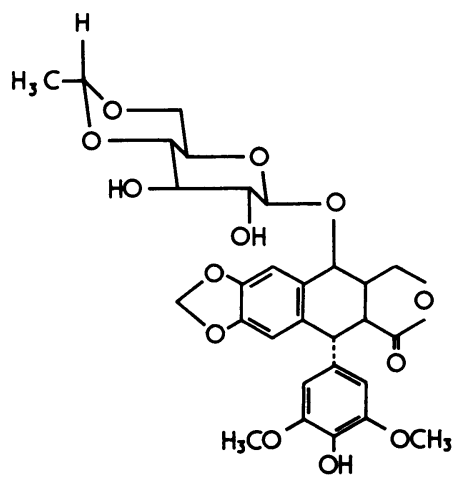

4'-Demethyl-epipodophyllotoxin- $\beta$-D-ethylidene glucoside

disease, and monocytoid leukaemia were especially included in the trial.

\section{Patients and Methods}

Patients. - Of the 250 patients admitted to the trial seven had acute lymphoid leukaemia, four had acute myeloid leukaemia, four had acute monocytoid leukaemia, four had acute myelomonocytoid leukaemia, two had poorly-differentiated leukaemic lymphosarcoma, and one had malignant histiocytosis-a total of 22 patients with acute leukaemia. There were 15 patients with Hodgkin's disease, eight with poorly-differentiated lymphosarcomas, 21 with poorly- or well-differentiated reticulosarcomas -in all, 44 patients with malignant lymphomas. There were 184 patients with metastatic solid tumours.

Drug Administration.-The drug was given intravenously to 200 patients in a dose of $50 \mathrm{mg} / \mathrm{m}^{2} /$ day for five days and orally to 50 patients in a dose of $100 \mathrm{mg} / \mathrm{m}^{2} /$ day for five days. Five-day courses of treatment were repeated at intervals of from five to 25 days.

\section{Results}

SIDE EFFECTS

The haematological side effects of VP 16213 are shown in table I. Haemopoietic depression was seen in $30 \%$ of the patients with an isolated leucopenia (less than 2,000 leucocytes $/ \mathrm{mm}^{2}$ ) in 40 patients, an isolated thrombocytopenia (less than 100,000 platelets $/ \mathrm{mm}^{3}$ ) in 17 patients, and a pancytopenia in 16 patients (fatal in two cases).

Among other toxic effects were alopecia, which occurred in

TABLE I-Haematological Side Effects of VP 16213

\begin{tabular}{|c|c|c|c|c|c|c|c|c|c|c|}
\hline & Dia & 1osis & & & $\begin{array}{l}\text { No. of } \\
\text { Cases }\end{array}$ & $\begin{array}{l}\text { Neutropenia } \\
\left(2,000 / \mathrm{mm}^{2}\right)\end{array}$ & $\begin{array}{c}\text { Thrombocytopenia } \\
\left(100,000 / \mathrm{mm}^{3}\right)\end{array}$ & Pancytopenia & $\begin{array}{l}\text { Persisting } \\
\text { cytopenia } \ddagger\end{array}$ & $\begin{array}{c}\text { Good } \\
\text { Tolerance }\end{array}$ \\
\hline $\begin{array}{l}\text { Acute leukaemia } \\
\text { Malignant lymphoma } \\
\text { Solid tumours .. }\end{array}$ & $\cdots$ & $\begin{array}{l}\cdots \\
\cdots \\
\cdots\end{array}$ & $\begin{array}{l}. . \\
\cdots \\
.\end{array}$ & $\begin{array}{l}\cdots \\
\cdots \\
\cdots\end{array}$ & $\begin{array}{r}22 \\
44 \\
184\end{array}$ & $\begin{array}{r}2 \\
5 \\
33\end{array}$ & $\begin{array}{r}-3 \\
14\end{array}$ & $\begin{array}{l}3 \\
7 * \\
6 \dagger\end{array}$ & $\begin{array}{r}16 \\
1 \\
0\end{array}$ & $\begin{array}{r}1 \\
28 \\
131\end{array}$ \\
\hline Total .. & $\ldots$ & $\ldots$ & $\ldots$ & .. & 250 & 40 & 17 & 16 & 17 & 160 \\
\hline
\end{tabular}


$54(21 \%)$ of patients, and abdominal complaints such as nausea (22 patients), vomiting (25 patients), anorexia (11 patients), and pain, but these were all mild and did not interrupt treatment. Headache, a raised blood pressure, and fever were observed in six patients.

Immune depression was exceptional as measured by skin delayed hypersensitivity, which was not affected when the tests were positive before chemotherapy, and by immunoglobulin levels, which decreased in only four patients out of the 50 in which they were measured.

In summary, 114 patients showed no signs of toxicity, and in 85 side effects were negligible. Because of toxic effects the intervals between the cycles had to be increased in $\mathbf{4 0}$ patients but therapy had to be interrupted in only nine. Two patients died in marrow aplasia.

\section{ONCOSTATIC EFFECT}

Remission was defined as the apparent complete disappearance of the disease, including manifestations such as bone marrow depression, and remitting for at least a month.

Regression was defined as the apparent complete disappearance of the tumour though other manifestations such as cytopenia persisted.

Both remission and regression could be complete or incomplete. The assessment of whether the extent of the remission or regression was more or less than $50 \%$ was necessarily subjective.

Acute Leukaemia and Malignant Lymphoma.-No effect was observed in the cases of acute lymphoid or myeloid leukaemia, leukaemic lymphosarcoma, or malignant histiocytosis

TABLE II-Results of Treatment of Cases of Acute Leukaemia with VP 16213

\begin{tabular}{|c|c|c|c|c|c|c|c|c|c|c|c|c|}
\hline \multirow{2}{*}{$\begin{array}{l}\text { Type of } \\
\text { Acute } \\
\text { Leukaemia }\end{array}$} & \multirow{2}{*}{$\begin{array}{l}\text { No. of } \\
\text { Cases }\end{array}$} & \multirow{2}{*}{$\begin{array}{c}\text { Age } \\
\text { Range } \\
\text { (Years) }\end{array}$} & \multicolumn{2}{|c|}{ Sex } & \multicolumn{2}{|c|}{$\begin{array}{c}\text { Complete } \\
\text { Regressions }\end{array}$} & \multicolumn{2}{|c|}{ Regressions > $50 \%$} & \multicolumn{2}{|c|}{ Regressions $<50 \%$} & \multirow{2}{*}{$\begin{array}{c}\text { Total } \\
\text { Failures }\end{array}$} & \multirow[b]{2}{*}{$\begin{array}{c}\text { Evaluation } \\
\text { Not } \\
\text { Possible }\end{array}$} \\
\hline & & & F. & M. & $\begin{array}{c}\text { With } \\
\text { Complete } \\
\text { Remission }\end{array}$ & $\begin{array}{l}\text { Without } \\
\text { Complete } \\
\text { Remission }\end{array}$ & $\begin{array}{c}\text { With } \\
\text { Incomplete } \\
\text { Remission }\end{array}$ & $\begin{array}{c}\text { Without } \\
\text { Incomplete } \\
\text { Remission }\end{array}$ & $\begin{array}{c}\text { With } \\
\text { Incomplete } \\
\text { Remission }\end{array}$ & $\begin{array}{l}\text { Without } \\
\text { Incomplete } \\
\text { Remission }\end{array}$ & & \\
\hline $\begin{array}{ll}\text { Lymphoid.. } & \ldots \\
\text { Myeloid } & \ldots \\
\text { Monocytoid } & \ldots \\
\text { Myelomonocytoid } \\
\text { Lymphosarcoma } \\
\text { Malignant } \\
\text { histiocytosis }\end{array}$ & $\begin{array}{l}7 \\
4 \\
4 \\
4 \\
2 \\
1\end{array}$ & $\begin{array}{r}3-46 \\
4-53 \\
40-80 \\
1-82 \\
59-63 \\
21\end{array}$ & $\begin{array}{l}3 \\
3 \\
3 \\
4 \\
1\end{array}$ & $\begin{array}{l}4 \\
1 \\
1 \\
1 \\
1\end{array}$ & $\begin{array}{l}2 \\
2\end{array}$ & & & & 1 & $\begin{array}{l}1 \\
1\end{array}$ & $\begin{array}{l}6 \\
3 \\
2 \\
1 \\
1\end{array}$ & 1 \\
\hline Total & 22 & & 14 & 8 & 4 & & & & 1 & 2 & 13 & 2 \\
\hline
\end{tabular}

TABLE III-Results of Treatment of Cases of Hodgkin's Disease, Reticulosarco ma, and Lymphosarcoma With VP 16213

\begin{tabular}{|c|c|c|c|c|c|c|c|c|c|c|c|c|}
\hline \multirow[b]{2}{*}{ Disease } & \multirow{2}{*}{$\begin{array}{l}\text { No. of } \\
\text { Cases }\end{array}$} & \multirow{2}{*}{$\begin{array}{c}\text { Age } \\
\text { Range } \\
\text { (Years) }\end{array}$} & \multicolumn{2}{|c|}{ Sex } & \multicolumn{2}{|c|}{$\begin{array}{c}\text { Complete } \\
\text { Regressions }\end{array}$} & \multicolumn{2}{|c|}{ Regressions $>50 \%$} & \multicolumn{2}{|c|}{ Regressions < $50 \%$} & \multirow{2}{*}{$\begin{array}{c}\text { Total } \\
\text { Failures }\end{array}$} & \multirow{2}{*}{$\begin{array}{c}\text { Evaluation } \\
\text { Not } \\
\text { Possible }\end{array}$} \\
\hline & & & F. & M. & $\begin{array}{l}\text { With } \\
\text { Complete } \\
\text { Remission }\end{array}$ & $\begin{array}{l}\text { Without } \\
\text { Complete } \\
\text { Remission }\end{array}$ & $\begin{array}{c}\text { With } \\
\text { Incomplete } \\
\text { Remission }\end{array}$ & $\begin{array}{c}\text { Without } \\
\text { Incomplete } \\
\text { Remission }\end{array}$ & $\begin{array}{c}\text { With } \\
\text { Incomplete } \\
\text { Remission }\end{array}$ & $\begin{array}{l}\text { Without } \\
\text { Incomplete } \\
\text { Remission }\end{array}$ & & \\
\hline $\begin{array}{l}\text { Hodgkin's disease } \\
\text { Reticulosarcoma .. } \\
\text { Lymphosarcoma .. }\end{array}$ & $\begin{array}{r}15 \\
21 \\
8\end{array}$ & $\begin{array}{l}15-63 \\
17-76 \\
42-75\end{array}$ & $\begin{array}{l}7 \\
8 \\
3\end{array}$ & $\begin{array}{r}8 \\
13 \\
5\end{array}$ & & 1 & $\begin{array}{l}1 \\
1 \\
1\end{array}$ & $\begin{array}{l}1 \\
2 \\
1\end{array}$ & 1 & $\begin{array}{l}1 \\
5 \\
3\end{array}$ & $\begin{array}{r}11 \\
11 \\
2\end{array}$ & $\begin{array}{l}1 \\
1\end{array}$ \\
\hline Total & 44 & & 18 & 26 & & 1 & 3 & 4 & 1 & 9 & 24 & 2 \\
\hline
\end{tabular}

TABLE IV-Results of Treatment of Various Solid Tumours with VP 16213

\begin{tabular}{|c|c|c|c|c|c|c|c|c|c|c|c|c|}
\hline \multirow{2}{*}{$\begin{array}{l}\text { Tumour } \\
\text { Site } \\
\text { or Type }\end{array}$} & \multirow{2}{*}{$\begin{array}{l}\text { No. of } \\
\text { Cases }\end{array}$} & \multirow{2}{*}{$\begin{array}{c}\text { Age } \\
\text { Range } \\
\text { (Years) }\end{array}$} & \multicolumn{2}{|c|}{ Sex } & \multicolumn{2}{|c|}{$\begin{array}{c}\text { Complete } \\
\text { Regressions }\end{array}$} & \multicolumn{2}{|c|}{ Regressions > $>50 \%$} & \multicolumn{2}{|c|}{ Regressions $<50 \%$} & \multirow{2}{*}{$\begin{array}{c}\text { Total } \\
\text { Failure }\end{array}$} & \multirow{2}{*}{$\begin{array}{c}\text { Evaluation } \\
\text { Not } \\
\text { Possible }\end{array}$} \\
\hline & & & F. & M. & $\begin{array}{c}\text { With } \\
\text { Complete } \\
\text { Remission }\end{array}$ & $\begin{array}{l}\text { Without } \\
\text { Complete } \\
\text { Remission }\end{array}$ & $\begin{array}{c}\text { With } \\
\text { Incomplete } \\
\text { Remission }\end{array}$ & $\begin{array}{c}\text { Without } \\
\text { Incomplete } \\
\text { Remission }\end{array}$ & $\begin{array}{c}\text { With } \\
\text { Incomplete } \\
\text { Remission }\end{array}$ & $\begin{array}{c}\text { Without } \\
\text { Incomplete } \\
\text { Remission }\end{array}$ & & \\
\hline 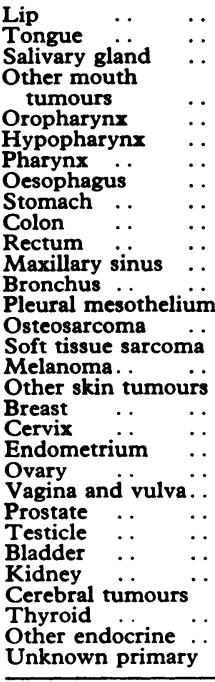 & $\begin{array}{r}1 \\
5 \\
4 \\
4 \\
9 \\
10 \\
1 \\
6 \\
4 \\
3 \\
1 \\
1 \\
6 \\
1 \\
5 \\
17 \\
11 \\
1 \\
41 \\
5 \\
8 \\
8 \\
2 \\
1 \\
4 \\
5 \\
4 \\
2 \\
1 \\
2 \\
11 \\
\end{array}$ & $\begin{array}{c}48 \\
60-65 \\
56-59 \\
58-73 \\
43-66 \\
35-71 \\
66 \\
42-73 \\
64-73 \\
42-67 \\
66 \\
50 \\
22-80 \\
54 \\
26-45 \\
24-49 \\
39-74 \\
62 \\
30-87 \\
29-71 \\
43-79 \\
49-69 \\
41-75 \\
64 \\
20-29 \\
49-78 \\
31-53 \\
34-59 \\
43 \\
55-70 \\
39-76 \\
\end{array}$ & $\begin{array}{l}\bar{Z} \\
2 \\
= \\
\overline{-} \\
1 \\
2 \\
= \\
= \\
2 \\
8 \\
8 \\
41 \\
5 \\
8 \\
8 \\
= \\
=1 \\
1 \\
1 \\
2 \\
\end{array}$ & $\begin{array}{r}1 \\
5 \\
2 \\
4 \\
9 \\
10 \\
1 \\
5 \\
2 \\
2 \\
1 \\
1 \\
6 \\
1 \\
3 \\
9 \\
3 \\
1 \\
= \\
= \\
= \\
1 \\
4 \\
5 \\
1 \\
\\
9 \\
\end{array}$ & & & $\begin{array}{l}1 \\
1 \\
1\end{array}$ & 1 & $\begin{array}{l}1 \\
7 \\
1 \\
1 \\
1\end{array}$ & $\begin{array}{l}2 \\
1 \\
3 \\
1 \\
1\end{array}$ & $\begin{array}{r}1 \\
5 \\
2 \\
4 \\
4 \\
7 \\
1 \\
4 \\
3 \\
3 \\
1 \\
1 \\
6 \\
1 \\
5 \\
15 \\
9 \\
28 \\
4 \\
6 \\
6 \\
2 \\
1 \\
3 \\
4 \\
3 \\
1 \\
1 \\
10 \\
\end{array}$ & $\begin{array}{l}2 \\
1\end{array}$ \\
\hline Total & 184 & & 95 & 89 & & & 7 & 1 & 12 & 19 & 141 & 4 \\
\hline
\end{tabular}




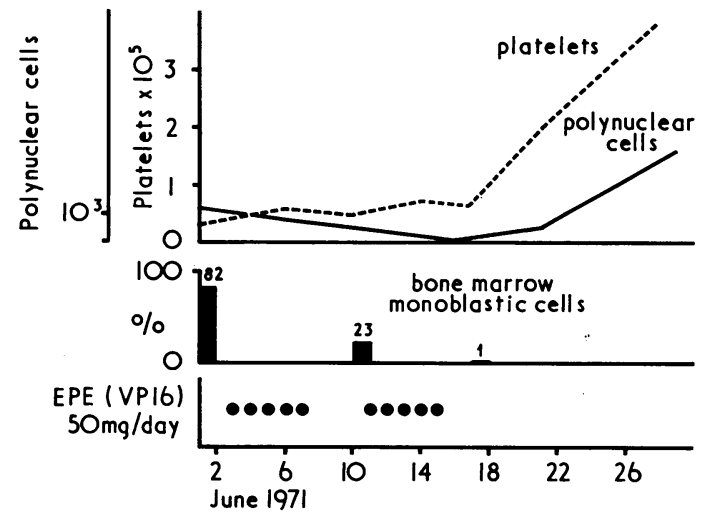

FIG. 1-Complete regression with complete remission obtained in a woman aged 80 with acute monocytoid leukaemia. EPE (VP 16) = Glucoside 4'-demethyl-epipodophyllotoxine- $\beta$-D-ethylidene.
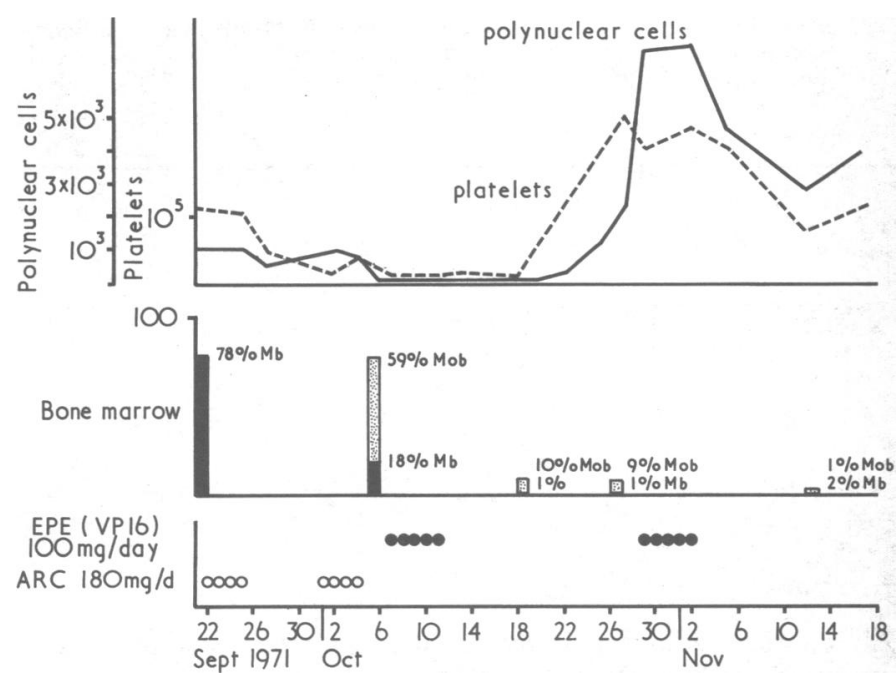

FIG. 2-Complete regression with complete remission obtained in a 67-yearold woman with myelomonocytoid leukaemia first treated by cytosine arabinoside (ARC) followed by VP 16213. The myeloblasts (Mb) regressed with ARC, the monoblasts (Mob) with VP 16213.

(table II). Four apparently complete remissions were observed among the cases of acute monocytoid (two out of four) and acute myelomonocytoid (two out of four) leukaemia (fig. 1). Thus there seemed to be a sort of specificity for monocytoid leukaemic cells. This point was illustrated particularly by the cases of myelomonocytoid leukaemia in which the myeloblasts disappeared only after a course of cystosine arabinoside, letting the monocytoid cells proliferate. The latter disappeared after treatment with VP 16213 (fig. 2). Given our previous results with VM 26, which was effective in cases of reticulosarcoma, and given the similarity of the drugs as well as the known similarity of monocytes and histiocytes, we hoped that the VP 16213 might prove highly effective in cases of reticulosarcoma. In fact, we obtained only one complete regression and three incomplete regressions of more than $50 \%$ out of 21 patients (table III), which is less than was obtained with VM 26 (E.O.R.T.C., 1972). In the cases of Hodgkin's disease there were two incomplete regressions of more than $50 \%$ among 15 patients. The result was even poorer in lymphosarcoma (two incomplete regressions of more than $50 \%$ out of eight patients). Thus VP 16213 seemed to be more specific for the monocytes than for the histiocytes. There was only one death among the patients with acute leukaemia or malignant lymphoma. The death was due to chemotherapy.

Solid Tumours.-Incomplete but pronounced regressions (more than $50 \%$ ) were observed in cases of melanoma and of

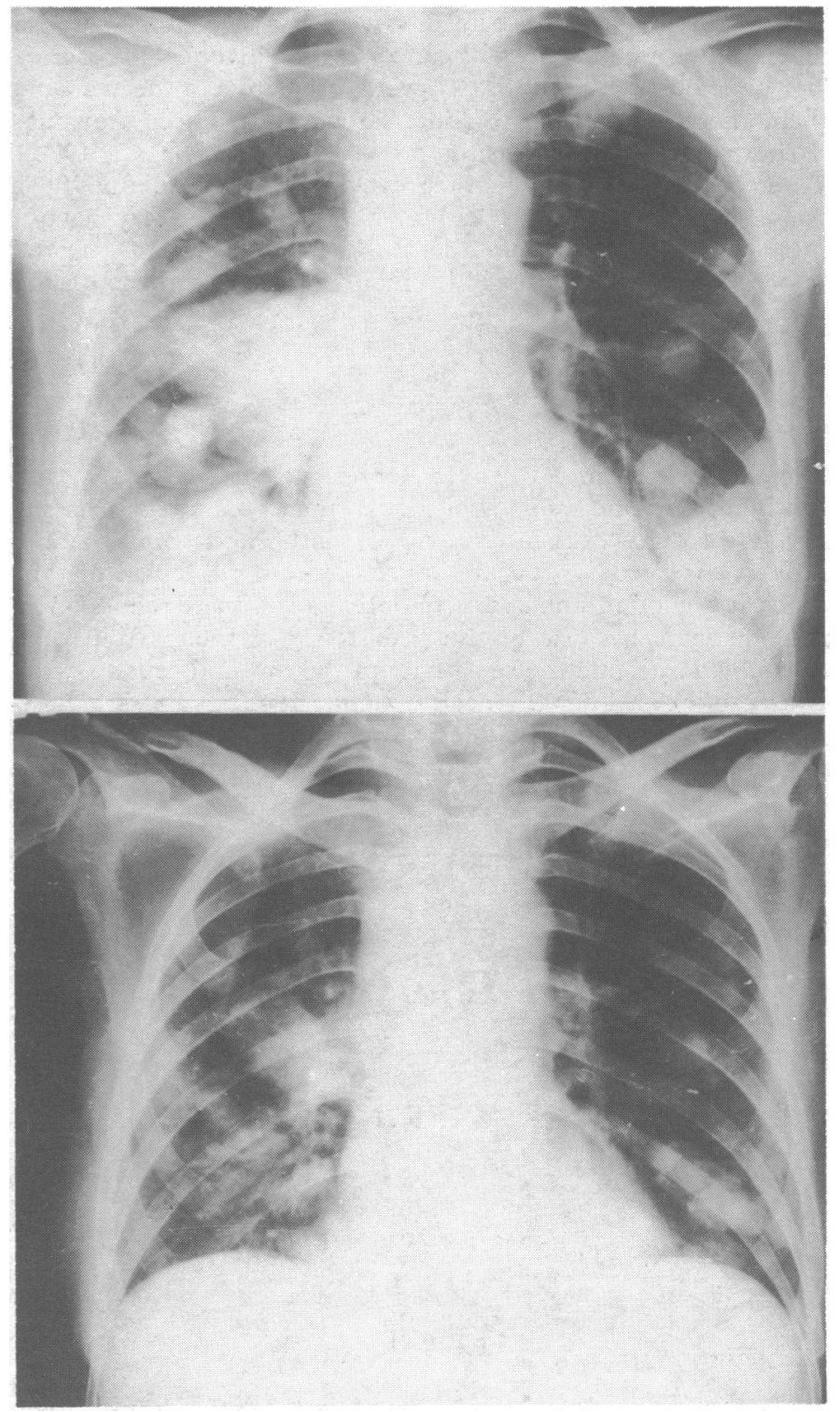

FIG. 3-Complete regression of a pulmonary metastasis from a renal carcinoma in a 48-year-old woman after treatment with VP 16213.

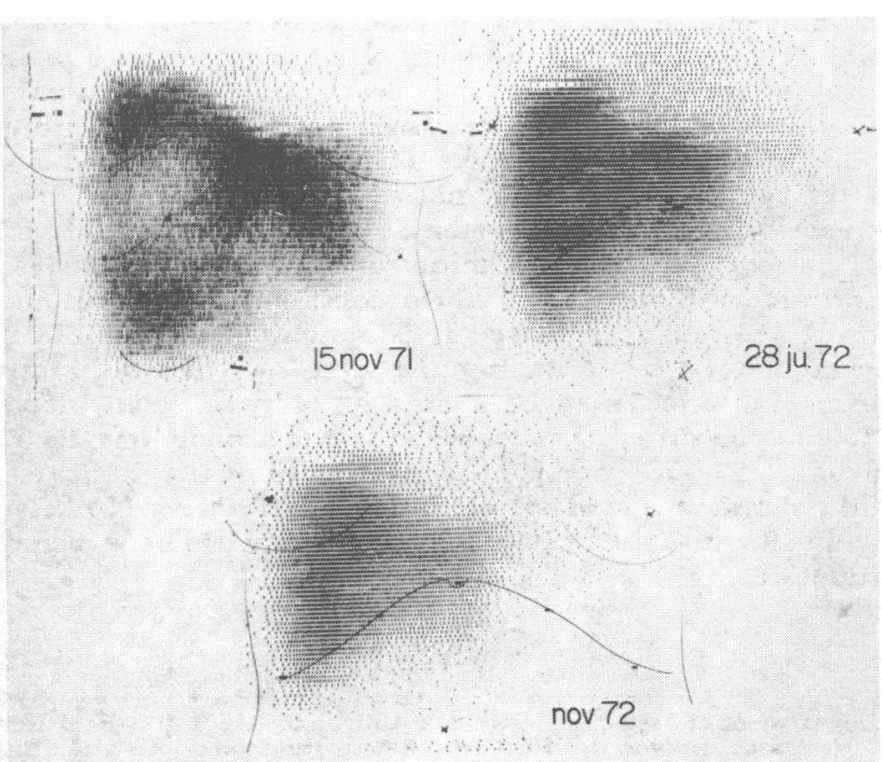

FIG. 4-Complete regression of a hepatic metastasis from a thyroid cancer after treatment with VP 16213. 
carcinoma of the oesophagus, breast, bladder, kidney, and thyroid (table IV). These results were not negligible because some of the tumours, such as cancers of the bladder, the kidney (fig. 3), and the thyroid (fig. 4), were insensitive to the available chemotherapeutic agents. Bladder carcinoma had been previously shown by us to be sensitive to VM 26 (E.O.R.T.C., 1972). Three of the tumours which regressed were in the pleura. That again suggests that VP 16213 as well as VM 26 may have a special affinity for mesothelia. There were 15 deaths among the patients with solid tumours. Only one of the deaths was due to chemotherapy.

\section{Discussion}

Epipodophyllotoxin VP 16213 represents an advance in the treatment of acute monocytoid leukaemia, which has been insensitive to any drug up till now (Mathé and Kenis, 1973). This is also true for acute myelomonocytoid leukaemia, in which it was often impossible to obtain a complete remission in some patients because of the persistence of monocytoid cells in the blood despite the sensitivity of the myeloid cells to cytosine arabinoside (fig. 3) (Mathé et al., 1973). VP 16213 also seems to be effective in bladder, kidney, and thyroid carcinomas, against which the available drugs were currently doing very badly (except VM 26 for bladder cancer). The Urology Cooperative Group of E.O.R.T.C. is to conduct further phase II or phase III trials of VP 16213 in the treatment of bladder cancers, with more patients under different conditions.

VP 16213 exercises some effect on cases of reticulosarcoma, Hodgkin's disease, melanoma, and carcinoma of breast and ovary, for which there are other active drugs. Thus operational trials will be conducted by the different Co-operative Groups of E.O.R.T.C. in these areas.

\section{VP 16213 was supplied by Sandoz Laboratory.}

Requests for reprints should be addressed to: Institut de Cancerologie et d'Immunogenétique, Hôpital Paul-Brousse, 14-16 avenue Paul-Vaillant Couturier, 94800-Villejuif, France.

\section{References}

E.O.R.T.C., Co-operative Group for Leukaemias and Haematosarcomas (1972). British Medical Fournal, 2, 744.

Mathé, G., and Kenis, Y., (1973). La Chimiothérapie des Cancers (Leucémies, Hématosarcomes et Tumeurs Solides) à l'Usage du Praticine, 3rd edn. vol. 1 . Paris, Expansion Scientfique Française. In press.

Mathé, G., Pouillart, P., Hayat, M., Steresco, M., and Lafleur, M. (1973) In Acute Leukemias Nomenclature, Classification, Clinical Trials, Methodology and Actuarial Results, ed. G. Mathe, P. Pouillart and L. Schwodology and Actuarial Results, ed. G. Mathe, P. Pot

Stahelin, H. (1970). European fournal of Cancer, 6, 211.

\title{
Abdominal Bruit after Renal Transplantation
}

\author{
S. J. JACHUCK, R. WILKINSON
}

British Medical fournal, 1972, 3, 202-203

\section{Summary}

Forty-seven recipients of renal allografts have been studied at varying intervals of up to five years after transplantation. Renal artery bruit occurred in eight of 16 patients observed over the first two post-transplant months and disappeared spontaneously in four of these. The disappearance of the bruit was associated with poor renal function. Renal bruits were audible in 10 patients examined more than two months after transplantation; nine of these were hypertensive and of six in whom arteriography was performed five were shown to have stenosis of the allograft artery. By contrast only eight of 37 patients without abdominal bruit were hypertensive, and arteriography in 10 normotensive patients without bruit showed no stenosis. It is concluded that while a renal artery bruit during the first two months after transplantation may be a marker of good renal blood flow at the time, its presence suggests a poor long-term prognosis since persistence of the murmur indicates that significant stenosis of the allograft artery is likely, while its disappearance is associated with poor renal function.

\footnotetext{
Department of Medicine, Newcastle University Medical School and Newcastle University Hospitals, Newcastle upon Tyne NE4 6BE S. J. JACHUCK, B.sC., M.B., Registrar Physician

R. WILKINSON, M.B., M.R.C.P., Consultant Physician and Senior Lecturer
}

Introduction

Abdominal bruit is a useful clinical sign in the diagnosis of renovascular hypertension (Simon et al., 1972). In renal transplant recipients bruits over the allograft renal artery have been regarded on the one hand as a sign of narrowing of the artery (Kincaid-Smith et al., 1969), and on the other as a sign of good renal perfusion (Braun, 1972; Anderson et al., 1973). This conflicting evidence on the significance of arterial bruits prompted us to review our surviving renal transplant recipients in order to determine the relation of bruit to hypertension and to graft function.

\section{Patients and Methods}

Forty-seven recipients of renal allografts were studied from two to 60 months after transplantation. Sixteen of these patients were also studied during the first eight postoperative weeks. In 26 patients the donor was a relative, in the remaining 21 cadaver kidneys were used.

Blood pressure was recorded in the supine position and hypertension defined as a persistently raised diastolic blood pressure above $100 \mathrm{~mm} \mathrm{Hg}$. Abdominal auscultation was carried out in the mid-line above and below the umbilicus, over the medial border of the transplanted kidney, and over the femoral arteries.

Selective arteriography of the allograft artery was performed in seven patients because of hypertension and in 10 without hypertension or rejection as part of a separate study.

In those 16 patients observed over the first eight weeks after transplantation daily blood counts and renal function tests were performed as well as clinical assessment for evidence of 